\title{
Introducción al Estudio de las Idolatrías *
}

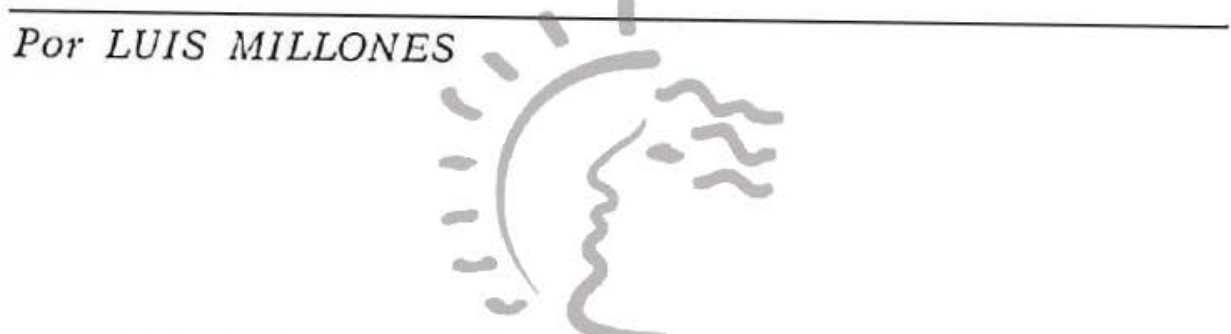

INTRODUCCION, El presente es un estudio inconcluso, desde su título se puede advertie su carácter introductorio al que reconozco sin duda como ambicioso, sobre todo, en tanto que tocará un problema hasta ell momento relegado a las "historias de la iglesia", desvirtuándose en ellas su principal característica de síntoma del proceso de transculturación que afrontaron las civilizaciones prehispánicas a partir del XVI. Justamente el carácter de esta historia (de la iglesia); dicho de otra manera, su naturaleza especial, particular o ancilar, limitó ya los alcances de sus cultores para descubrir en las "idolatrías" toda la gama de elementos de transición característicos de una sociedad en conflicto. En otras palabras, este fenómeno fue desglosado del contexto social de la época para convertirse en un rebrote circunstancial y difuso de las religiones precolombinas en una anomalía del cristianismo, al parecer única y todopoderosa religión del virreinato.

El tema ha sido presentado fundamentalmente como un inconveniente inevitable en el transcurso de la evangelización,

* El presente trabajo es un resumen de la tesis del autor. Por comodidad y espacio se han suprimido las citas bibliográficas que le otorgaba rigurosidad; de todos modos, al final, se incluye la blbliografía correspondiente. 
ha sido parte incidental en la propagación del catolicismo y en el caso peruano específicamente, ha quedado liquidado como enfrentamiento entre religión inca y predicación española, con el lógico triunfo de la cruz de los invasores.

Me parece urgente abandonar estos criterios simplistas, hay hasta el momento la recopilación ordenạda y verificada de los relatos de los conquistadores; pienso que debemos dejar hablar a los vencidos, no sólo para escuchar su versión de la conquista, sino porque hasta que no confrontemos ambos testimonios jamás sabremos los alcances de la propia evangelización hispana.

Cabe una advertencia, a lo largo del trabajo se mencionarán instituciones religiosas hispanas, pero en ningún momento se intentará su estudio sino a partir de lo que aquellas significaron para los indígenas; no es ésta una nueva historia de la iglesia, es un intento de averiguar el pensamiento religioso aborigen a partir de la crisis de Cajamarca. Un duro inconveniente para la realización del mismo resulta la carencia de un estudio serio sobre los cultos precolombinos; la biblografía, a pesar de su amplitud, se circunscribe a inútiles repeticiones de las versiones de los cronistas españoles, más el ocasional añadido de tales o cuales ideas generales sobre religión aplicadas de manera arbitraria y formada a la inca. Ha sido pues, necesario descartar fo que podria haberse constituido en un valioso elemento comparativo, quedando forzados a ensayar una investigación preliminar que pueda servir de peldaño al estudio de los vacíos anotados. Vamos a desenvolvernos en lo que aparece como de mayor impacto religioso en el indígena a partir de 1532 , intentaremos descubrir las consecuencias de la imposición de esta nueva ideología, pensando no sólo en cómo recibió la doctrina católica, sino, aún más, en la reinterpretación que necesariamente hizo de la misma.

Una imprescindible advertencia: nuestra labor se va a desenvolver teniendo como marco cronológico 1532-1616 aproximadamente, creemos que lo dicho puede extenderse aún más en la Colonia, pero el material con que contamos nos restringe a ese período. Igualmente lo consideramos válido sólo para el área andina, obviamente usaremos ejemplos mexicanos o de otras zonas en tanto que los patrones de comportamiento de evangelizadores y naturales sean coincidentes con lo sucedido en nuestro territorio. 


\section{CARACTERES EXTERNOS DE LA EVANGELIZACION EN EL PERU OUE INCIDEN FN IIA MFNTALIDAD RELIGIOSA DEL GRUPO VENCIDO}

1. Catolicismo especial de los españoles.

2. Incertidumbre en la presentación de su doctrina.

3. Persecución y pasividad frente a las idolatrías.

No vamos a repetir conceptos conocidos acerca de la actitud inicial del clero español en el Nuevo Mundo; es ya ampliamente sabido cómo a raíz de la Reconquista, !lega a América con el impulso inicial de "espada de Cristo", frente a los musulmanes. Esta disposición sufre algunas modificaciones en el desarrollo de la empresa conquistadora; el clero que llega al Perú ha ganado el intenso adiestramiento de las misiones en las Antillas y sobre todo en México, lo que hace que tenga más o menos delineadas ciertas normas de actividad - no metodología- frente a los futuros conversos. Los españoles van a empezar haciendo tabla rasa con la religión oficial de los vencidos en todas lás manifestaciones que son capaces de descubrir, para luego contemporizar con ellos utilizando la simbología popular aborigen en la búsqueda de un acercamiento a nivel de profundidad, esta posterior pasividad, acremente criticada por los organismos superiores de la Iglesia, se rompió únicamente cuando las condiciones socio-económicas crearon en:lajindígena la necesidad de una ruptura del sistema español, en otras palabras, al estallido de movimientos revitalistas ođ mesiânicosn el bien cuando la administración española por razones de su propia organización lo dispuso.

Algo no trabajado, es el estudio de la conquista y colonización como movimiento migratorio, si tal existiera seria mucho más fácil determinar la extracción social de los españoles que cruzaron el Atlántico y con ella saldrían a flote las diversas maneras de comprensión de su propia religión que el mismo grupo invasor traía consigo. Esto es sumamente importante, especialmente porque debemos de señalar como premisa de nuestro trabajo las diversas "formas de catolicismo" que llegaron al Tahuantinsuyo, debemos contar, por ejemplo, con aquél que trajeron y difundieron los propios conquistadores o las creencias que hicieron circular los esclavos negros, distintas ambas de la prédica habitual de los sacerdotes, la que, desde ya adelantamos, no sonaba igual a los oidos de los indígenas si partía de clérigos o religiosos, o de orden a orden. Por lo demás, y aquí remarcamos como cosa capital, el cristianismo de los conquistadores a pesar de su experiencia ca- 
tequística, llegó con seria incertidumbre en cuanto a la presentación de su doctrina: "Constitución 38․ Contiene la Ins. trucción acerca de la doctrina yue se ha de enseñar a los in. dios. Primeramente se les diga la diferencia que hay entre nosotros los hombres todos y los demás animales brutos, que cuando ellos mueren ánima y cuterpo juntamente muere...".

Si esto consta nada menos que en el Primer Concilio Limense, es lógico imaginar lo que rodaba popularmente en boca de doctrineros menos versados que Loayza; por ello se llegó a prohibir la circulación de ciertas cartillas, habituales e incongruentes guías de los misioneros.

Los factores delineados (incertidumbre en la presentación de la doctrina y diversa extracción social de los primeros españoles) conforman el perfil hispano de un nuevo elemento cultural: la idolatría, tipicamente colonial, verdadera amalgama de elementos cristianos y aborígenes.

Todas ellas arrastran un considerable bagaje de la agresiva e inorgánica prédica española, que presentada de manera multiforme impactó en la mentalidad nativa tiñendo en adelante toda manifestación religiosa. Todavía más, el sacerdote no intentó separar los elementos de la propia tradición indígena de lo que él estaba acostumbrado a castigar, al menos en la confesión : en sus compatriotas: culando planificó este sacramento entremezcló en las pregumtas lo que su cultura le indicaba como supersticiones. Esto hecho, dada la fuerza impositiva con que sé aplicó la Penitencia, fue configurando en los aborígenes al lado de sus cultos locales, y junto con los rezagos de la antigua religión oficial por lo menos dos nuevos factores: a) Las creencias populares españolas condenadas por su iglesia y lógicamente aceptadas al mismo nivel que las suyas por los bisoños cristianos y, b) la prédica que reinterpretada por el indígena va a țomar nuevas valencias conformando un cuadro religioso especial, cuyo esquema intentaremos descubrir.

Un interesante punto de partida es el problema de la traducción: es evidente que ello preocupó a las esferas eclesiásticas aunque sólo ocasionalmente percibieron los verdaderos alcances de una total deformación en tanto que se anunciaba el dogma cristiano. No se trata exclusivamente de la traslación de un idioma a otro, cuestión mucho más compleja de lo que se piensa (la mayoría de los indígenas tenían que retraducir de su idioma nativo al runa simi y de allí al castellano), 
pensamos que desde los primeros instantes los intérpretes o las desaforadas señas de los misioneros crearon una versión muy especial del catolicismo peculiarizada aún más posteriormente por los factores ya enunciados.

A su llegada el clero español ya sabe de la necesidad impostergable de usar intérpretes, más tarde se hará cargo de la urgencia de saber por sí mismo el idioma, situación, que, como veremos, en el fondo no transforma para el aborigen el sentido de la prédica. En México se había experimentado el fracaso de las simples señas frente a un auditorio que naturalmente se hacía las más contradictorias conjeturas, "Como no sabían la lengua, no decían sino que en el infierno, señalando la parte baja de la tierra con la mano, había fuego, sapos y culebras, y acabando de decir ésto, elevaban los ojos al cielo, diciendo que un solo Dios estaba arriba, ansí mismo apuntando con la mano, lo cual decían siempre en los mercados y donde había junta y congregación de gentes y no sabían decir otras palabras que los naturales les entendieron sino por señas; y cuando estas cosas decían y predicaban, el uno de ellos que era un viejo calvo $y$ venerable, estaba en la fuerza del sol de mediodía $\mathrm{y}$ a medianoche en muy altas voces que se convirtiesen a Dios y dejasen las idolatrias. Cuando predicaban estas cosas decían los señores caciques qué han estos pobres miserables? mirad si tienen hambre, y si han de menester algo, dadles de comer, otros decían: estos pobres deben ser enfermos o estar locos, dejadlos vocear a los miserables tomándoles a lsu mal ede locura, dejadlos estar, que pasen su enfermedad como pudieren, no les hagáis mal al cabo estos y los demás se han de morir de esta enfermedad de locura, y mirad si habéis notado cómo a mediodía, a medianoche y al cuarto del alba, cuando todos se regocijan, estos dan voces y lloran; sin duda ninguna es mal grande el que deben de tener, porque son hombres sin sentido, que no buscan placer ni contento sino tristeza y soledad".

El usar intérpretes tuvo consecuencias interesantes e inmediatas, en primer lugar se formó en torno al sacerdote (personaje que resultaba claramente diferenciable en la hueste conquistadora) todo un grupo especial de indígenas que obtuvieron el inmediato prestigio de comunicarse, y además de manera mágica, con el grupo vencedor. Este fenómeno (al que dedicamos luego un aparte), en cuanto traductores, significó la difusión, desde los inicios de la conquista, de todo un conjunto abigarrado de nociones religiosas entremezcladas, no sólo por la doble o triple traslación de idiomas que 
se veían obligados a realizar sino por las dificultades que resultaban de buscar equivalentes a la terminología cristiana: “...y como han oido predicar que el Espiritu Santo vino en lengua de fucgo sobre los Apóstoles, atribuyen el nombre de Dios, Espíritu Santo, al fuego, entendiendo por él a st، dios, que es el fuego" (1). Si a esto añadimos que ni predicadores ni "lenguas" eran representativos de la cultura intelectual de ambas civilizaciones, concluiremos de manera fácil que las primeras "herejias" salieron de boca de los doctrineros.

Basta reflexionar un instante acerca de la extraña situación de intermediarios entre una cultura y otra que los traductores afrontaban diariamente, para retroceder sobre la inmensa bibliografía que atribuye este hecho a "ignorancia de los indios", o más "científicamente" a la imposibilidad de traducir conceptos abstractos de una religión superior. El intérprete se hallaba desconcertado entre dos mundos, cambiaba al runa simi palabras que se sustentaban en estructuras lógicas diferentes, e ideas que correspondian a una escala de valores esencialmente distinta a la suya; pensando en ésto la muy conocida versión de Gareilaso acerca del encuentro Valverde-Felipillo con Atahualpa cobra nuevas tonalidades: "... por decir Dios Trino y Uno, dijo (Felipillo): Dios tres y uno son cuatro, sumando los números por darse a entender..."

Desaparecido el intérprete o al menos atenuada su actividad como tal, el sacerdote, a pesar del dominio de la lengua indígena, debe apelar igualmente a elementos culturales autóctonos para hacer efectiva su ibra; essasí como el kipu aparece como auxiliar mnemotécnico en la Confesión, o bien el uso de "figurillas de barro, de harina o madera", para "objetivar los simbolos más abstractos", el resultado no se hizo esperar: señales de metal entregadas a los indios como comprobante de haberse confesado aparecieron en el "ornato de una Huaca".

Hemos hablado acerca del carácter agresivo de la evangelización, ello influyó de manera determinante en la persecución masiva que inicialmente se llevó contra todo lo que resumaba características religiosas autóctonas. Esto último conviene tenerlo muy presente en tanto que los doctrineros procedieron de acuerdo a los patrones medioevales que regían su propia conducta, pues a partir de ellos van a surgir innumerables ordenanzas y confesionarios en los que se indica

(1) Ybot León, Antonio La iglesia y los eclesiásticos españoles en la empresa de Indias. Barcelona, Salvat Editores, S.A.. 1954, pp. 578-579. 
desde la manera de preguntar al indígena durante la Penitencia, hasta los castigos que se aplicaban en caso de idolatría. Es típico de esta situación la naturaleza estamental de las penas y la dicotomía Dios-Demonio con que se separan y reagrupan las creencias de la épọca. De ahí surgen una serie de dificultades para el estudio propuesto; conocemos sola. mente las fuentes que indican lo que a juicio de los españoles era religioso en los indios y, además, esto mismo presupone una reinterpretación hispana ("cosas del demonio") de los datos, que ya filtrados por su mentalidad, llegaban a sus manos.

Al principio, en tanto que "extirpadores", fue escasa la tarea de los sacerdotes: la primera hueste arrasó con los santuarios en busca de riquezas, y lo ligado que (por lo menos lo que se puede inferir de las crónicas) estuvieron el estado y clero incaicos dio como resultado la inmediata desaparición del estrato social adscrito a la religión oficial; sin embargo se puede decir que, en general, algunos elementos perduraron fuertemente aculturados o bien se fundieron en cultos locales menos perceptibles a la vista de los españoles aunque también afectados por la invasión. Más adelante la prédica insistió con notable agudeza en el "pecado de los mayores" tratando de desvirtuar lo poco que sobrevivía del credo estatal incaico, en realidad, ya no era necesario; la muerte de Atahualpa, de extraordinaria repercusión en el indígena, marcó de manera indeleble el fin del Tahuantinsuyo a pesar de los "inkas de Vilcabamba'oteca de Letras

A la descomposición del neofeudalismo en el Perú, tipificado por los encomenderos, el clero reafirma sus derechos en las doctrinas haciendo, desde este momento, una labor aparentemente más sólida. No obstante y tal como lo advierte Avila, el clima de confianza que existió acerca de los fcligreses hizo doblemente inútil su tarea: la mentalidad aborigen ya había elaborado los mecanismos capaces de mantener la vigencia de las formas religiosas resultantes del schok cultural, todo esfuerzo católico o nativo de reorganizar para sí los sentimientos de la sociedad vencida fracasaron totalmente; los primeros porque desconociendo las características del complejo cultural andino desarrollaron un sistema represivo que aunque impresionante (visitas, extirpadores, fiscales, cárceles, azotes) no logró sino, en última instancia, crear situaciones de conflicto y los segundos (de lo que sólo tenemos un ejemplo) porque su propia vida se asentaba en elementos muertos del Tahuantinsuyo y la transformación de la socie- 
dad corría a cargo de una intervención sagrada a la que el débil foco de Vilcabamba no fue capaz de auxiliar.

Analizaremos a continuación los intentos de la iglesia dirigidos a la organización de su grey; con esto cerramos (de manera imperfecta y transitoria) el conjunto de caracteres externos de la cvangelización que influyen de manera perceptible en el indígena. Reiteramos el propósito de dirigir la investigación a los efectos de dicha circunstancia en el grupo vencido; el desarrollo histórico de las visitas o los cambios de administración eclesiástica súlo nos interesarán en razón de la importancia medida a través de un ángulo lo más cercano posible a quienes sufrieron la persecución religiosa.

Hemos visto cómo globalmente la evangelización es irregular y sigue de cerca los vaivenes de la politica española en América. La reorganización fue planteada muchas veces y en diferentes tonos por toda clase de funcionarios coloniales, su aplicación y consecuencia (materia que nos preocupa) dejará en el indígena huellas muy precisas, sobre todo en función de la visita eclesiástica, institúción máxima de control en la iglesia americana. Por lo demás, y ésta es la premisa con que partimos, todo intento de encausar la fe de los vasallos tue entendido por éstos a través de los castigos, circunstancia que reconocieron y legislaron los españoles.

Quien estudie los sistemas de extirpación de idolatrías se encontrará con un pavoroso euadro-en el que no falta el menor elemento para un relatol de terror ö"s..y de cada pueblo sacaréis algunos de los que fueren más culpados, sin tener respeto a que sean tributarios o no, a que sean viejos, o pobres o enfermos, ni otro respeto humano, sino sólo rociando (sic) la gloria y servicio de nuestro señor y bien de las almas $\ldots$ Y el gasto que se hiciere en llevarlos desde sus pueblos a dicha reclusión sea a costo de los mesmos indios culpados...". (2). Pero nosotros no pasaremos revista a las normas efectivas del castigo a los idólatras: trabajos forzados, cárcel, azotes, etc., que en el fondo representaban un seguro freno a la multiplicidad de formas religiosas que se venian desarrollando. Lo verdaderamente signiticativo son las sanciones de orden social que acompañaba y se complementaban con los ya citados. El evangelizador percibe de manera muy concreta algunos valores típicos de las culturas andinas y se vale de ellos

(2) (Borja, Francisco de) Extirpación de Idolntrías. En: Diez documentos del siglo XVI. Revista del A:chivo Histórico, Año IV, No 4., Cuzco Editorial H. G. Rosas S. A.., 1953. pp. $221-222$. 
para golpear de manera aplastante a quienes descubre evidencia de idolatría.

Anteriormente señalamos el sentido estamental del castigo, creo que esta es una de sus principales caracteristicas. El curaca, alcalde o alguacil, aún reconocido como "maestro dogmatizador" sufrirá una pena distinta a la del indio común, conectada con el ejercicio de su cargo: será destituido o bien encerrado en "una casa a manera de cárcel"; a su vez quienes hubieran sido penados por dicha razón o simplemente por encubridores de los delincuentes, perdían para siempre la posibilidad de alcanzar tales rangos, Acosta nos proporciona la explicación de su época para esta diferenciación en el sistema de castigos: "Sea, pues, este el primer precepto para extirpar la idolatría quitarla primero de los corazones, sobre todo de los reyes, curacas y principales a cuya autoridad ceden los demás prontamente y con gusto". Sin embargo una mirada global al proceso de la colonia nos advierte la urgente necesidad que tuvo la metrópoli de mantener consigo a los curacas, tanto es así que en Chiapas (1584) - y con toda seguridad encontraremos ejemplares en el área andina - se descubre y hace confesar a toda una organización de "idólatras" a los que no se pudieron castigar gracias a la ardorosa defensa del corregidor, a la que oportunamente se sumó la audiencia, en retribución del buen desempeño del cacique Juan Atonal, jefe de los "doce apóstoles", como tributario.

El hatun runa no tuvo tanta suerte, fue sometido, desde principios del XVII, a tuac vigilaneial estrecha cuyo detallismo puede sorprendernos pero revela la incomprensión y desconfianza entre ambos mundos. Así por ejemplo se legisló hasta en "ciertas maneras de torcer o hacer trenza de los cavellos... que los indios usan para sus supersticiones..."; sin embargo, en el mismo Concilio, nueve disposiciones después se permitía: “...usar (de los) médicos, empíricos y desperiencia..." ( ${ }^{3}$ ) es decir, potencialmente los mejor capacitados por el prestigio de su propio quehacer para suscitar las idolatrías, tanto más si usualmente ellas van a reaparecer a raíz de la muerte: el frecuente robo de cadáveres en las iglesias y la restitución de los mismos a las prácticas pre-hispánicas tuvo sus mejores instigadores en los "médicos" indígenas.

No obstante, y tal como lo hemos apuntado, el sacerdote católico intuyó o descubrió algunos mecanismos culturales an-

(3) Se trata del 2: Concilio Limense. Vargas Ugarte, Rubén. Concilios Limenses (1551_1772). Lima, Talleres Gráficos de la Tipografía Peruana S.A., Rávago e Hijus, 1951, Tumo 1, p. 225. 
dinos por lo que su castigo adquirió mayores proporciones. Esencialmente captaron la significación del carácter comunitario de la vida indígena, aunque no pensaron en la aplicación general de este postulado sino más bien ajustado a casos especificos. Es por eso que aparecen el destierro, el trasquile de los cabellos y la segregación de las ceremonias cristianas como penas mayores, a las que se agregaba, dosificando de acuerdo al grado de participación y reincidencia, cárcel y azotes. También, y esto desde Cajamarca, el misionero descubrió el temor especial de los aborígenes a que sus cadáveres fueran quemados; en base a ello legisló dicho castigo para todos los "infieles" o suicidas, que evidentemente fueron muchos más de lo que se supone, tanto que una pieza teatral muy posterior llega a señalar dicha circunstancia.

En general el clero utilizú dos técnicas muy prácticas y de inmediato resultado en una sociedad tan especial como fue la del XVI: denuncia y retractación. Es ilustrativo para esto último la presentación de los ya prisioneros, lideres del Taki ongoy: "...se desdijeron de todo lo que habian dicho y predicado contra la ley evangélica con muchas lágrimas se convirtieron y pidieron al pueblo perdón...". La denuncia aparece ubicada con regularidad en las instrucciones para sacerdotes: se fomenta entre los miembros de una comunidad o se contrata a gente ya habituada a esos menesteres, que a decir de Guamán Poma supieron aprovechar la coyuntura para utilizar en su favor las ventajas de sursituaciōn intermedia, aunque más de uno pagó caro el entrometerse en servicio de los blancos.

Algunas consecuencias de las penas fueron observadas por las mismas autoridades; frente al destierro Avila recomienda prudencia: "Esto ha de menester muy buena deliberación y acuerdo porque en parte del corregimiento de Guarochirí y en el de los Yau (yos) más de mil Maestros y en sacando éstos sea de atender que se han de sacar otras 2 mil personas porque al marido hạ de seguir la mujer, y al Padre el Hijo, etc. Y en breves días se han de huir todos y en no juntando $y$ castigando los huidos han de entender que es todo cosa de burla. Y si se ha de tratar de que se visite lo restante del Arzobispado conviene disimular con estos hasta que todo se acabe porque los no visitados retardarán de dezir la verdad y manifestarse viendo que castigan con destierro a los que lo hazen". En cuanto a las cárceles debe anotarse la Real Cédu. la por la que se prohibió inútilmente su existencia $\left({ }^{4}\right)$, ya or-

(4) Lissón Chávez, Emilio. La Iglesia de España en el Perú. Sección Primera. Archivo Gencral de Indias, sin pic de imprenta, 1943, vol. III, No 14 p.451. 
ganizada y legislada dentro de la colonia; la fama de la presión emplazada en el Cercado de Lima trascendió las fronteras del virreinato peruano aunque su población más o menos escasa, fue, al parecer, restringida a los "hechiceros" más connotados esto se debía a que en general cada doctrina se preocupó de encarcelar a los que descubría en su territorio. La justicia en estos casos dejaba muchas dudas en pie, incluso para los mismos españoles: "Estos indios que están presos por hechiceros les hacen trabajar los dichos religiosos en hacer ropa $v$ otras cosas para ellos, según declaran ciertos indios de Pomata como Vuestra Señoría lo podía mandar que lo que éstos trabajasen cuando estuvieren presos fuese para ellos y para pagar sus tributos y cumplir sus necesidades".

Sin embargo escapó a los españoles un corolario muy lógico: los penados adquirían a propósito de las mismas sanciones, prestigio frente a su pueblo: "...pues sacando a uno, el más culpado, con su coroza y como penitente, no sólo no mostró estarlo, más con toda resolución y descaramiento, viendo que algunos de los espanoles circunvecinos que habían acudido a ver esta justicia se reían de él, por ser el más conocido, les dijo de qué se rếan? pues no era maravilla que a él lo castigasen siendo indio, pues también castigaban españoles por semejantes delitos".

Dejamos para el final una-revisión de los intentos nativos de reorganización de su "material" sagrado; el más ligero análisis nos muestralun fracasoGabsoluto de parte de la iglesia española en tanto que ninguna de las "extirpaciones" alcanzó su meta, a pesar, de lo drástico de sus procedimientos reconocemos naturalmente que lo dicho es válido en el marco cronológico de nuestro estudio; a decir de Arguedas, la situación presente es análoga, creemos que una investigación metódica de las fuentes del XVII en adelante daría fuerza a la afirmación del citado antropólogo.

\section{CARACTERES INTERNOS}

\section{La Prédica. Contenido formal y consecuencia.}

Nos toca enfrentar un problema cuya envergadura excede las posibilidades de cualquier estudioso en estos momentos. Aprehender aquellas ideas que deslizándose de la intención de los evangelizadores produjeron determinadas reacciones y cuáles fueron ellas, resulta una labor para la que no contamos con las fuentes ni el aparato teórico suficiente. Por ello 
esta parte del trabajo tendría la sola misión de dar el toque de alarma que encamine futuras investigaciones.

Hasta donde conocemos se descubren cuatro (deben ser muchos más) elementos sumamente fusionados -la separación solamente obedece a razones didácticas- cuya influencia en el indigena resulta notoria, ellos son: el pecado, la otra vida, sexo y demonio, tal vez deberíamos añadir los sueños pero es un tema para el que tenemos pocos datos y muy precario conocimiento.

Es evidente que, para el pensamiento católico español de la época, la idea de pecado resultaba dominante, si revisamos con cuidado los documentos, observaremos que cada elemento tiene su particular recepción y respuesta de los "naturales". Podemos presumir que ello se debió a diversas causas más o menos diferenciables que se conjugaban, así por ejemplo, la idea del demonio cristiano ha debido enzarzarse con algunas deidades prehispánicas y adquirir nuevos atributos ya "mestızos" sobre todo en momentos de crisis tal como se nos plantea en la Idolatria de indios Hliachos.. . pero las diversas formas de asimilación a nivel local y cronológico hacen muy difícil determinarlas.

a) Noción del Pecado: angustia como fruto del shock cultural, el "pecado de los mayores". Cada vez se delinea con méjor precisión la situación de crisis del indígena del siglo XVI, los nuevos estudios demográficos nos presentan una brusquísima caída en la curva dépoblación que cubre toda la etapa estudiada, índice más que suficiente de la mencionada crisis; a partir de esto se observa que si bien racionalmente no entendió lo que estaba sucediendo (todavía no lo entendemos nosotros) al menos logró percibir de manera difusa pero relevante la transformación de su sociedad. Esto no se debió a ninguna especulación teórica, la vida cotidiana le daba suficientes elementos para captar la "anormalidad" en que transcurría su existencia: descomposición de la familia, migraciones forzadas, servidumbre, etc. Frente a este cuadro la religión católica le proporcionó los elementos precisos para una interpretación del mundo discordante que lo rodeaba, y ésta interpretación cuyo esquema apenas empezamos a conocer tenía su punto de partida en el pecado.

A través del formidable efecto del sermón en runa simi el misionero pudo presentar la doctrina en sus más conmovedores matices gracias a la riqueza idiomática de elementos afec- 
tivos, más aún, a ello agregó: “...ejemplos espantosos...” y lienzos pintados con "... un alma condenada que en todo mostraba los horrores de su desesperación...". Por el sermón y su incansable muletilla, el pecado, los cristianos dieron de manera reiterada y masiva una explicación del cambio que atravesaba la vida del indigena; pero hay algo más, la miseria de su existencia arrastraba también el "pecado de sus mayores": "si tus antepasados adoraron Huacos no tenían luz de la ley de Dios, ni conocían a Dios, sino al Demonio, que los traía engañados; y por este pecado los condenó para siempre". En una sociedad basada íntegramente en las relaciones de parentesco, el trauma que produjo esta declaración es indescriptible. Sólo así se explica la desesperación con que se perseguia a los sacerdotes en busca de absolución, sobre todo porque la Confesión llevó al plano personal la vivencia de pecado en que se desenvolvía el indigena de ésta época. Agreguemos también que el sentimiento de culpa tomó cuerpo a raíz de la progresiva comprensión del status de raza sometida al que estaban adscritos. El indio era un ser vencido y su misma derrota tuvo ya, las explicaciones teológicas que en última instancia fueron proporcionadas por los invasores: "Hicieron notar los misioneros que los dioses no habían sido capaces de librarles de la conquista española...", la situación se hace más precisa en la literatura quechua colonial que reinterpreta el motivo con el agravante de cierto matíz premonitorio: "En mis sueños (habla Sayri Túpac) he visto a Tukuy Jallp'a/ y he oido de sus labios que ella quiere $p$ a esos barbudos" $(5)$. Y aún en la más fervorosa efervescencia de unalirecomposición de la sociedad perdida, el aborigen repite el argumento de su derrota como punto de partida: los españoles vencieron porque Cristo había hecho lo propio con las huacas.

Debemos considerar sin embargo que su noción de culpa distaba mucho de la inculcada por los evangelizadores, ajenos a las particulares transgresiones de la religión en que hubiese incurrido, el nuevo cristiano sentía el peso de la destrucción de su cultura que había asociado a la idea de pecado y su angustia no se resolvía en la confesión, ni siquiera en los instantes previos a la muerte donde los sacerdotes tuvieron que luchar a brazo partido con los "hechiceros", con los parientes que preferían recurrir a sus propias deidades e incluso con el moribundo que vacila frente a las dos tradiciones.

Quizá por ello, entre otras cosas, la noción del más allá

(5) La: a, Jesus. Tragedla del fin de Atawallpa. Cochabamba. Imp:enta Universitaria, 1957 p. 105 . 
andino fue diversa o simplemente no existió en términos europeos; es dable pensar que la multiforme existencia parahumana de los difuntos constituyó uno de los muchos escapes a la terrible disyuntiva cielo infierno propuesta por el clero, dando lugar a una expiación post morten no prevista en la doctrina católica.

\section{b) La Prédica y el sexo}

Un tema de sumo interés es el que abordamos ahora, resulta incuestionable que la evangelización española concorde con sus patrones culturales, insistió denodadamente en la sistematización del comportamiento sexual de los indígenas. Ya sabemos que fue muy pobre el ejemplo que sobre ello pudo dar, cualquier página de Guamán Poma es representativa de lo que realmente sucedió, pero aun ignorando las normas de la vida familiar pre-hispánica podemos aseverar que era la primera vez que el sexo tenía un lugar preponderante en ella. Más todavía, dado el sistema de parentesco paralelo que parece propio de la cultura andina e intraductible a la terminología hispana se podían suscitar los más escandalosos casos de incesto a raíz de una simplísima afirmación del indigena "me casé con mi hermana"; cuando en realidad la multiud de parientes a quienes llamaba hermano o hermana lo alejaban por completo de la sanción católicas Et aj̃o pasado (1964) en Ayacucho era posible hallar "hermanos por juramento", circunstancia sellada poŕruna ceremonla cemla quo poco tiene que hacer la autoridad eclesiástica ${ }^{(6)}$.

Todos los días y especialmente los festivos el doctrinero resaltaba de manera nítida la nueva importancia del sexo que que el aborigen estaba lejos de entender mucho menos en el sentido de pecado con que invariablemente concluía el sacerdote. Era muy difícil para un español que había visto "monjas" en los Acllahuasi o multitud de "esposas" en torno del Inca desglosar de su mente la visión oriental hispánica que importó desde Europa a "las Indias Occidentales", en base a esto había organizado una prédica cuyas características encajaban perfectamente con los "errores" previsibles en su coterráneos pero que nada tenían que ver con la cultura andina. Un ejemplo que tipifica lo dicho es la reglamentación del castigo por blasfemia al indígena, absolutamente inútil desde esa fecha hasta nuestros días, en cambio lógico para el invasor.

(6) Versićn recogida por el autor. 
Además no podemos ignorar que en la multitud de culturas que poblaban el Tahuantinsuyo, existieron variantes de mayor o menor grado con respecto al modelo ideal cuzqueño con el que funcionó de manera tan precaria la evangelización católica; es por este doble defecto de apreciación que hoy día nos cuesta mucho entender, por ejemplo, a qué se refieren los "extirpadores" cuando hablan de "casas públicas" de homosexuales "en los Yauyos". Lo que sí advertimos es que la connotación moral que intentó trasplantar el misionero se estrelló con la recíproca incomprensión de ambos grupos.

Es así como se va elaborando en base a la plática incisiva una nueva figura del sexo, ahora en un conjunto de reglas violentamente arbitrarias para el vencido; las que sin embargo, coinciden con un fenómeno típico de éste período histórico y mucho más complejo: el decrecimiento de la natalidad aborigen.

Al momento nos faltan datos para hilvanar el comportamiento sexual y la prédica sobre el mismo, verbigracia no alcanzamos a descubrir el papel del demonio como "incubu" y "súcubu" dentro de una misma familia tal como lo describe el documento de "...los indios huachos ...". Es indudable que se percibe la forzada mano del "extirpador" cargando sobre las espaldas del diablo los efectos de una evangelización equivocada, pero más allá de lo que se pueda entender por intervención demoníaca thayala aceptaciónsde dicha circunstancia por los indígenas, es decir, se estaba creando, al menos en esa zona de Huancavelica, una nueva forma de trato sexual que aunque imaginaria ponía algo o alguien entre marido y mujer, haciendo de la relación algo culpable e infecundo.

\section{c) El demonio}

Pocas figuras sagradas que importara la predicación europea han tenido tan recio impacto como la del demonio. Si en muchas partes hemos señalado nuestra incapacidad para entender medianamente los temas propuestos, en este caso la situación cobra dramática expresividad que nos limitaremos a indicar lo que tenemos entrevisto.

Empezaremos por considerar que la multifacética manifestación del diablo en la cultura católica española del XVI ya da un índice de los diversos caminos de asimilación que facilita esta figura, sobre todo si pensamos que la grosera simplificación del misionero adjudicó a la obra del "enemigo" 
todas las creencias religiosas de los aborígenes; de esta manera organizaba sin pensarlo dos grandes esquemas cuya conexión él mismo se encargó de realizar.

Al igual que todos los fenómenos religiosos acarreados por la invasión europea su estudio nos lleva a una inevitable comparación con la expansión del culto cuzqueño (declaramos nuevamente nuestra ignorancia sobre este tema, las conclusiones son pues meras hipótesis cuando hablamos de religión oficial), por la lectura de las crónicas conjeturamos que el estado inca respetó los cultos locales, añadiendo cuando fue preciso sus propias divinidades o bien trasladando él, en primer lugar, las ofrendas a los dioses regionales, esto ya nos da una norma de comportamiento en lo religioso del indígena, el aparecer de una nueva iglesia estatal no lo obliga, por lo menos hasta la extirpación organizada de idolatrías, a romper con su propia tradición que había soportado sin demasiados problemas la conquista del Tahuantinsuyo. Además, no sabemos hasta qué punto se podrá hablar de tal ruptura en tanto que no implica la renuncia de sus religiones, ya avivadas por la ausencia del control incaico, tampoco se puede decir que la iglesia europea ingresó por el mismo cauce y con las mismas posibilidades y problemas que la del Tahuantinsuyo, de hecho se apoyó más en una nueva e insólita coyuntura histórica que fue la Conquista. Nacida de ella tenía que arrastrar necesariamente la situación de conflicto que esto significaba.

Planteado así el panorama mos encontramos con que el análisis del "demonio" reviste por lo menos las siguientes dificultades: a) es un elemento muy particular (polifacético y ligado al sentimiento de culpa) dentro de su propio contexto religioso; b) llega conjuntamente con la destrucción del poder estatal y participa en la elaboración de la sociedad traumatizada que inmediatamente se desarrolla; c) su arribo coincide con un período especial en la cultura andina, se encontraban en período de conjunción dos sistemas de vida diferentes: regional y estatal y d) la tendencia ya mencionada de los evangelizadores en relacionar al demonio con las creencias pre-hispánicas abre un nuevo cauce de comunicación entre ambos.

La investigación que nos proponemos tropieza con un grave inconveniente: las fuentes. Provenientes en su mayoría de misioneros tienen la insistencia que señalamos y es difícil saber si las afirmaciones registradas provienen de la concepción particular de ellos o de las reinterpretaciones del grupo aborigen. Esta situación se agrava en tanto que una revisión del 
material etnográfico más conocido nos indica una escasa o nula participación del demonio en su contexto religioso, salvo que su asimilación sea tal que a nuestra vista se torne irreconocible.

Para ejemplificar lo dicho basta con enumerar las característica que un solo documento nos menciona, $\left({ }^{7}\right)$ de acuerdo con él el diablo se presenta como: "enano", "negro", "nublado de forma humana", "remolino de viento y aire", "ñusta de rostro blanco y hermoso", "inga"; tiene los siguientes atributos: "muy feo y mal olor", "frío y de mal olor", "no era tan teo", "de buen talle", "piel cenicienta, amoratada", "carne blanda como las demás personas", "vestido de varios colores entre verde y negro", "vestido feo y desarrapado", "uñas de bestia en manos y pies", "con alas", "voz gruesa, desentonada y ronca", "hablaba con gravedad", "andaba a saltitos", "aloncillo, (??)" y "tridente para amenazar"; y por último goza de los poderes que siguen: "aparecía en sueños", "echaba fuego por la boca moderadamente", "podía tocar pero no ser tocado", "Ilora por la venida de los curas", "deja señales de fuego a las personas que toca" "pronuncia suaves y melosas palabras", "cura con hierbas", "promete ayudar y no cumple", "al acostarse halla desnudo sin desnudarse", "pide niños e indios sin bautizar".

Como se ve el problema es vasto, una simple clasificación no nos sirve, pensamos que dacomparación de los motivos enunciados con los atributos de los "condenados" del actual folklore andino nos puede dar una pista, cuyo remate lógico debe ser el análisis en profundidad de cada uno de ellos.

\section{d) La idea de la otra vida}

Muy ligada a la noción de pecado aparece la idea del más allá, ya hemos observado como las concepciones de cielo e infierno aunque traumatizaron de manera profunda la mentalidad aborigen no pudieron polarizar situaciones de eternidad tal como lo planteaba la iglesia católica. La concepción postmorten del indigena, difiere tanto del europeo que al suponerlas no se halla ninguna trabazón posible, de allí que la única salida posible haya sido la reconstrucción de las ideas cristianas a partir de patrones autóctonos. Nos bastará un detalle que aunque escapa del marco religioso sirve para probar lo dicho, mientras la muerte para un español constituía un mo-

(7) Anónimo. Idolatria de los indios Huachos y Yauyos. En Revista Histćrica, tomo VIII, entrega II. Lima. Instituto Histórico del Perú, 1919, pp.191-195. 
mento importante en la vida de los herederos en tanto que significaba acceso a bienes para el indigena esto mismo se logra de manera más precisa a través del matrimonio.

El total desajuste que existe entre las nociones religiosas cristianas de la muerte y cualquicr forma de existencia posterior a ella con la de los "naturales" al revés de lo que se pudiera pensar no hace más fácil la tarea, mucho menos si el XVI constituye una fase especial del mundo andino ya que señala todo un gran período de transición en el que las formas religiosas están en constante reclaboración.

Podemos notar algunas características que comparadas con las actuales concepciones indigenas más o menos organizadas abrirán posibilidades de investigación. En primer lugar reafirmamos la hipótesis enunciada líneas arriba: en las fuentes no aparecen las ideas de cielo e infierno como definitivos y opuestos, el indígena creó una serie de existencias intermedias que contemplaron aspectos de uno y otro sin arribar a las conclusiones de premio o castigo final que si existieron, no excluían las mencionadas. Las ideas de los "condenados" ya mencionada es un claro esfuerzo para evitar esta trágica disyuntiva, por ella siempre existe la posibilidad de "salvación" tan nítidamente pintada en los cuentos del ucumari.

Es interesante que cuando se habla de la otra vida, en cualquier caso selmenciona como lugar donde se come y bebe bien, primarias aspiraciones queclan sociedad les negaba: “... muchas veces los convidó (el demonio) con el infierno, diciéndoles que había allá mucho contento, fiestas, comida, bebida, $\mathrm{y}$ no lo que los españoles y padres predicaban, que era mentira; y los exhortaba a que se ahorcaran o se echasen en el río". Se podría pensar que esto es neto producto de una contraevangelización como parece haber sido la que provocó esta visita y por tanto no representativa de una idea usual del más allá, pero el padre Recio nos trae el relato de una niña a la que la Virgen María conduce al paraíso, de regreso: "Dábanle de comer, pero ella no arrostraba en cosa de la tierra, después de haber gustado los regalitos del cielo", en ambos casos por no citar más se nota la inmediata proyección de uno de los problemas de la sociedad vencida. Y algo muy importante el rechazo a determinados elementos europeos (ropas, etc.), así como la adaptación de otros (cerdos, etc.) en función de sus propios patrones de cultura. El sueño de Guamán Poma transcrito en su "Buen Gobierno" era también el de la nueva sociedad que se formaba. 
Otro aspecto digno de destacar es que la forma de arribar a éste "otro mundo" se va acentuando en torno al suicidio y que éste aparece como ahorcamiento, no creo que esto sea casual, el suicidio indigena en el XVI parece mucho más general de lo que habitualmente se piensa y es probable que el ahorcarse tenga un sentido especial dentro de su forma de pensamiento.

No podemos establecer líneas de conexión con explicaciones modernas a partir de trabajos etnográficos aunque probablemente la analogía sea mucho más cercana que con la figura del demonio hoy de importancia difusa y disminuida en nuestro campesinado. Así por ejemplo en Puquio se cree que en las montañas "viven (...) los niños que murieron, habitan en un palacio deslumbrante donde hay jardines que cuidar y golosinas con que los infantes se alimentan". Pero se trata de meras aproximaciones, es evidente que hoy día ya se encuentran organizadas las creencias en la mayoría de grupos andinos que aunque su situación puede variar por la penetración de la cultura occidental de manera más nítida, de todos modos existe ya algo más o menos establecido cuyo estudio está dando sorprendentes resultados, es así como en el relato recogido por Ortiz Rescaniere en Vicos se presentan dos "redenciones", una moral en el infierno: "El alma de la gente va primero al infierno, después al cielo, todos tienen que ir primero al infierno a pagar sus pecados." "Es pecado morder la teta de la madre cuando somos niños tiernos". La otra redención es de carácter social. "En el cielo los indios hacen trabajar a los mistis a punta de chicote, como ellos nos hacen trabajar acá". Si nos atenemos a los textos, la sociedad indígena mantiene una imagen conflictiva del mundo, no pretendemos que sea la misma creada por la invasión europea ni mucho menos, pero sí es posible que su nueva elaboración responda a situaciones de presión social análogas.

\section{Los sacramentos}

a) De ingreso a la sociedad española: bautismo y matrimonio.

b) Confesión; confrontación individual con el pecado.

Recordamos claramente que a la pregunta de un conocido erudito peruano (Luis E. Valcárcel) una india monolingüe respondió: "Yo no entiendo el sermón ni la misa, pero vengo porque mi alma si lo entiende". Es la investigación sobre ac- 
titudes similares lo que nos interesa. Por ello apenas podemos sugerir algunas consideraciones que por lo evidentes han sido ya scñaladas aungue no desde el ingulo que nosotros perseguimos.

Parece muy claro que la iglesia española insistió sólo en tres sacramentos: bautismo, matrimonio y confesión, los demás aunque mencionados reiteradamenle no tuvieron el vigor de los anteriores e incluso se discute sobre la necesidad de administrarlos. Es claro que resultan vitales los tres indicados, sobre todo si pensamos en el establecimiento de la organización europea, ( $\sin$ que por ello ignoremos las connotaciones religiosas propias de la cultura española), el bautismo daba las cifras aproximadas de una futura mano de obra y aseguraba los límites jurisdiccionales de los misioneros; el matrimonio reorganizaba la sociedad pre-hispánica comprimiéndola a un sistema mucho más comprensible a los curopeos que ignoraban las formas de parentesco y las condiciones y privilegios del nuevo status de adultez; y la eonfesión que funcionaba como sistema de control ya que el "idololatra" era un elemento disociador en el imperio. colonial español.

Pero aparte de las consideraciones que puedan desprenderse de tales sacramentos debemos tener en cuenta las proyecciones que tuvieron como ceremonias visibles a los ojos asombrados del indígena. Al decir esto no pensamos en las inmediatas asociaciones quel hicieion fos cronistas al hablar de una "confesión" pre-hispánica del drutuchicubo del matrimonio "de prueba", "por compra", etc. de hecho dudamos que para los "naturales" las correspondencias hayan sido igualmente claras, más bien es preferible preguntarse qué clase de efecto pudieron tener el derramar agua sobre la cabeza del infante (o adulto), que los amancebados fueran castigados o que de pronto en uná violenta comprobación individual cada indígena sintiera sobre sí el peso de los "pecados" cuya expiación variaba desde ser materia de toda la comunidad hasta un problema personal e intransferible.

Las fuentes nos hablan de circunstancias sumamente interesantes: en Mixtón (Nucva Galicia 1541) los indígenas se sublevaron contra el clero y al momento de acoger a los que renegando del cristianismo se plegaban al movimiento, "les lavaban la cabeza para que les quitara el bautismo". En Michoacán los "hechiceros" hicieron creer a los indios que el agua bautismal era sangre y que al bautizar a los niños les hendian la cabeza, en el Perú a raíz del movimiento del Taki Ongoy 
(1565) son los "bautizados" los que acuden a seguirlo, esta es una de las razones por las que antes de pertenecer a él deben expiar su cristianidad mediante el ayuno y otras prácticas. De estos ejemplos se desprende que el carácter soteriológico (*) del sacramento quedó soslayado frente al significado práctico de su imposición: por él se ingresaba a una sociedad de la que, dado un momento de crisis, había que salir limpiando el rito que los había sellado como cristianos. Por lo demás, el bautismo, por lo menos en los primeros años, fue aplicado con el descuido que todos conocemos y recibido con el tenır que inspira un grupo que ha vencido y cuya presión aumentaba día a día, tanto es así que en Huancavelica hacia 1613 los indígenas escondían a su hijos para que al no figurar en los padrones parroquiales se librasen de la mita minera.

El matrimonio preocupó largamente al Estado español, desde un comienzo entendieron que la sociedad andina se organizaba en torno a la unidad doméstica, de ahí que las primeras informaciones de los visitadores usen de ella para sus estadísticas. Luego, si se proyectaba una reestructuración de todo el territorio invadido era necesario controlar la base de esta organización, naturalmente esto sólo se podría hacer dentro de un sistema comprensible a la mentalidad española y tal era el matrimonio cristiano. Muy pobre fue su arraigo en la masa dominada que mantuvo y mantiene sus costumbres tradicionales; hasta donde conocemos el matrimonio católico se usa solamente en razón de que acarrea situaciones de prestigio. Su imposición, desde un principio fue legislada y ejecutada con la premuirar de todaisociedach naciente, sin embargo no logró adentrarse en los aborígenes, en última instancia apoyados en el propio desorden de la estructura nuclear, nota típica del siglo XVI.

Ya hemos dicho que de todos los sacramentos es la confesión el que penetra con verdadera violencia en el pensamiento nativo. Creemos que su capacidad de llevar todo el sentido de la prédica a un plano personal poniendo en evidencia el conflicto cultural que vivía el nuevo cristiano fue el factor determinante para que traumatizara de manera tan elocuente que los documentos acusan una dramaticidad ajena a la fría narración de un suceso. Hasta donde sabemos la expiación comunitaria con toda su problemática parece haber sido lo característico del área andina tal cual aparece encuadrada en el relato que Molina nos transmite con cierta minuciosidad, fren-

(*) Carácter salvador del sacramento. 
te a esto el sacramento católico plantea el compromiso personal de asumir sobre si y de manera inmediata todo el conflicto que su sociedad vivia. Ello hizo que: "En ocasiones (...) no poderles cntender palabras, de los sollozos, ligrimas y otros expresivos sintomas de pesadumbre. Con algunos me ha acontecido - escribe el P. Francisco Medina- por parecerme que era necesario detenerle la absolución, echarse a mis pies con grandes lágrimas pidiéndome que por amor de Dios les diese la penitencia que quisiere, y no los dejase de absolver, y si no lo hacia entonces, regresaban al poco tiempo llenos de remordimiento insistiendo en la petición". Resulta, pues, que todo lo dicho en cuanto a la prédica y el pecado tiene su correlación personal a través de la confesión, es ahi donde el sacerdote con mucho más éxito que los propios tormentos obtenia las informaciones sobre "idolatrias" y podia, al plantear el destino post-morten del indigena, presionar de manera inquisitiva e íntima sobre los patrones de comportamiento aborigen. El miedo que inspiró dicho sacramento está pintado en lo que sigue: "Tomaron mucho temor de la confesión, pensando que el confesor los mataría. Si alguno se atrevia a afrontar ese terror, los demás se quedaban $\alpha$ la expectativa, mucho más si era mujer, mientras se confesaba y, al acabar, lo acababan a preguntas acerca de lo que habia hecho, qué le habian preguntado, qué había respondido" $\left.{ }^{8}\right)$. Más todavia, una revisión del cuestionario de Pérez Bocanegra confirma $\mathrm{cl}$ acerto, nadie en aquel momento hubiera podido responder a él sin plantearse de manera necesaria y descarnada (aunque sea inconscientemente) el examentectodoel proceso histórico que soportó el Tahuantinsuyo uccinelli Converson

\section{Simbolos externos}

\section{a) Templos y cruces sobre los santuarios pre-hispá- nicos.}

Un aparte sumamente complejo es el que afrontamos ahora especialmente porque poco se puede decir sobre él hasta que una serie organizada de estudios parciales nos den una pauta para ensayar conclusiones más o menos certeras. En efecto, careciendo de los antecedentes de cada recinto sagrado, teniendo en cuenta su posible función pre-hispánica, no podemos ni siquiera esbozar un análisis preliminar del problema, por ello nos limitaremos a indicar las dificultades que necesa-

(8) Ricard, Roberto. La conquista esplritual de México. México. Eclitorial Jus Polis, 1947.
pp.469-470. 
riamente deben salvar quienes enfrenten con mayor material este interesante aspecto de la catequisación.

Aun en el archirepetido caso Coricancha - Santo Domingonos falta un estudio serio sobre los antecedentes del templo incaico ya que de ninguna manera fue casual su descubrimiento como espacio sagrado por los españoles. Sería cuestión previa a toda investigación, el análisis de los relatos de las fuentes españolas pero no para recortar datos o forzar su encuadre dentro de una teoría general de la religión, sino buscando el hecho cultural detrás de cada palabra. Esto, claro, descle un punto de vista documental, esperamos con impaciencia que los arqueólogos al trabajar en sus restos salgan -y nosotros con ellos- de la mera descripción.

Dintinguiremos dos aspectos de la investigación como antecedentes necesarios; en primer lugar creemos que cada templo (en el que existan indicios de ocupación pre-hispánica o de particular devoción indigena en la primera época colonial) debe ser estudiado pensando en las circunstancias de su fundación: quien fue (orden religiosa, etc.) y si ello respondía a un problema especial o no (peste, apachetas, etc.) de esta manera tendremos algunos elementos que arrastra el establecimiento de la iglesia como tal, que tiñen de manera singular las relaciones de ella con su grey sobre todo si pensamos que existían determinadas imágenes a las que se les atribuía ciertas virtudes coherentes con el pensamiento de la época. Y, en segundo lugar, convieite trecalcar los elementos aborígenes que reconocieron como sagrado el espacio luego ocupado por la iglesia cristiana. Esto es mucho más complejo de lo que se supone sobre todo si recordamos que la conquista de los incas en la mayoría de los casos respetó y/o readaptó los santuarios regionales agregando nuevas valencias religiosas, esto supone ya un esfuerzo muy duro para un historiador cuya documentación apenas puede (hasta ahora) conducirlo al intermedio tardío. Y lo dicho nos lleva a una circunstancia muy especial, ciertas calidades inherentes a las divinidades respetadas en época pre-hispánica, al superponerse la iglesia católica van a ser transferidas al panteón cristiano. ¿De qué manera? ¿hasta qué grado?, ¿en qué zonas? son preguntas que no podemos responder, no obstante en el caso de la Virgen de Copacabana hay indicios de que esta situación se cumplió plenamente, por lo demás, en Guatemala en determinados casos se ha optado por permitir al mismo tiempo y en la propia iglesia el culto a las divinidades aborígenes.

No podemos abandonar este punto sin referimos a las 
personas adscritas al templo. A lo largo del XVI se va formando todo un grupo en torno a la iglesia que adquicre determinadas prerrogativas frente a su cultura, músicos. sacristancs, etc., van contormando un clemento nuevo que, queda vacilando como grupo intermedio. Lo interesante es que, casi siempre, son éstos quienes, por un evidente problema de prestigio, comandan a espaldas del sacerdote la "iclolatria" del lugar" usando como reliquias los despojos de la construccion prehispánica.

La importancia de las cruces en estas nuevas formas religiosas es difícil de precisar, a veces debido a la manera de su erección como instrumento de triunfo sobre las ruinas de una "huaca", creó resistencia inmediata, otras por el material de su construcción - restos del templo primitivo- inspiró una ulterior veneración. Pero la presentación de estos extremos puede ocultar la verdadera problemática, es posible suponer una serie de participaciones de la cruz en distintos niveles no excluyentes, sin embargo solo podemos hacer presunciones ya que carecemos de datos sulicientes; además la universalidad de la cruz como símbolo sagrado complica mucho más el panorama, ya sabemos que los espanoles encontraron cruces a su arribo al Perú y la frecuencia de ellas en el contexto de las construcciones y cacharros pre-colombinos, pero no tenemos ningún estudio previo que nos dé luz sobre el asunto. Hay un aspecto que conviene poner en cvidencia: la pertinaz insistencia del misionero para la colocación de este signo: "Item que todo indio xpiano tenga en su patio o en la puerta de su casa, una cruz para queJ todas lascyecesi quevlarvieren humillándose se acuerden de la pasión de Jesuxpto". Naturalmente a ello contribuyó el estratégico emplazamiento dado a las cruces que reasumían en otro contexto religioso la dirección de los elementos sagrados autóctonos.

Nos informan que se ha empezado a estudiar los diversos tipos de cruces en un área limitada y su función social, esto mismo, de aplicarse a los datos históricos daría luz sobre el problema, ya que, por ejemplo, la cruz levantada en la fundación de una ciudad pudo no tener iguales características que la alzada sobre una apacheta.

\section{b) Santos y milagros}

Es interesante cómo sobre este tema la primera pregun ta que se formulan folkloristas, antropólogos, historiadores, etc., es siempre el porqué del arraigo inmediato del culto a 
los santos, fenómeno tan evidente como de apariencia simple: una fácil explicación sería su ligazón a los estratos populares españoles y con ello la relación diaria de ofrendas, pedidos, etc., sobre cosas de pequeña e inmediata necesidad, el culto a los santos parece compatible con la idea de una (o menos dicho varias) religión popular pre-hispánica indemne de la primera arremetida evangelizadora, de ser esto cierto ambas formas religiosas por su carácter de asequibilidad a similares estratos sociales habrían tenido facilidad de interrelacionar sus elementos, ingresando los santos con status análogos en la mentalidad aborigen.

No vamos a presentar ninguna idea nueva, pero agregaremos algunas notas que pueden hacer más preciso al panorama anterior, al igual que en el caso de los templos es necesario investigar sobre los atributos de los santos; en general cada uno parece indicado para un determinado mal, pero todos refucrzan su condición de privilegio, en situaciones de crisis: la guerra, la peste, los temblores, etc., sin embargo aun en esos momentos sucede que determinado grupo de santos salten a una principalía no uisual.

Aunque hubiésemos querido no podemos hacer una ordenación ni siquicra tentativa de los santos de acuerdo a las cualidades atribuidas, su actuación en períodicos de crisis, zonas de influencias y circunstancias de su llegada, pero dejamos abierto el internogante con estos cuatro puntos que nos parccen previos.

\section{"Jorge Puccinelli Converso»}

El solo análisis de un caso: Santiago, ya ha sido materia para que se le dedique estudios más o menos largos, sobre él se ha descubierto desde su importancia chamánica hasta el carácter mesianico que en determinadas circunstancias alcanzó a tener.

Aunque con respecto al milagro la situación es similar hay algunos aspectos que nos parecen evidentes pero que hasta el momento han pasado desapercibidos. Ignoramos hasta qué punto la concepción europea del milagro podría haber tenido su correspondiente en el mundo andino, pero en el XVI ya se encucntra que ha tomado cuerpo en la naciente sociedad americana. Desde el sitio del Cuzco por Manco Inca los indígenas comparten con sus adversarios la aparición de Santiago y la Virgen María: "luego en aquélla hora hizo Dios otro milagro estando cercados todos los cristianos en la plaza del Cuzco estando haciendo oración, hincado de rodillas dando voces 
y llamando a Dios y a la Virgen Maria y a todos sus santos y santos ángeles, y decía, válgame la Virgen Maria, Madre de Dios hizo otro milagro muy grande. Milagro de la Madre de Dios en este reino y lo declaran y dan fe de ello como en aquel tiempo no había ninguna señora en todo el reino, ni jamás lo habían visto ni conocido, sino primera señora le conoció a la Virgen Maria", es curioso que otro idealista como era Garcilaso tenga una explicación racional al suceso ahora en el escenario costeño de la misma acción: "Ios indios familiares daban cuenta a sus amos de todo lo que sus contrarios hablaban y tenian. Los españoles habiendo notado las maravillas que Dios Nuestro Señor hacía por ellos, y sabiendo que los indios las sentian y hablaban en ellas, le daban gracias por todo $\mathrm{y}$ decían que aquel río (Rímac) había sido para cllos y para los indios lo que el mar Bermejo para el pucblo de Israel y para los egipcios", pero ni el espíritu renacentista del Inca podría hallar una elucidación precisa para la multitud de milagros que nos traen las fuentes de la época, desde castigos divinos por la profanación de una iglesia hasta la resurrección de muertos. Lo interesante es que el asunto tiene dos caras, en 1613 ya se encuentra el aprovechamiento de un solo acontecimiento por el saccrdote católico y el "jefe de idolatrías", en Huacra un rayo destruyo la iglesia, mientras el religioso explicaba el descuido a la easa de Dios y el consiguiente castigo, un "hechicero" decía lo mismo por la "huaca" sobre la que estaba construido el templo. Aún más hemos llegado a registrar milagros atribuiddos a-las deidadesaindigenas, inclusó por el propio clero espanot: Que Tevantando otra huaca llamada Huancamarca en el pujebldide chavín, mereertificó este saccrdote visitador que destiló de la piedra dos o tres gotas de sangre y en diez días no se le quitó la mancha del dedo con que la tocó", por si el ejemplo pareciera insuficiente unas lineas más abajo el mismo informante nos relata otro milagro mucho más espectacular: "Descubriendo cuatro huacas sucedicron algunas cosas raras y prodigiosas. La primera se llamaba Apu-huamarilla y de una figura feísima, la guardaba una india; cogióla el visitador y tiróla en su aposento y envió a llamar a la india para examinarla; y entrando por la puerta la india, la saludó el demonio diciéndole allí: Hamuy suma ñusta, seas muy bien venida princesa. El P. que oyó hablar la piedra se espantó y temió grandemente y quedó como desmayado; y la india empezó a hacer mil reverencias y animó al P. para que no temiese diciéndole: Mira P., es nuestro Dios. Esta piedra hiciéronla muchos pedazos y la quemaron".

La más somera revisión de este aspecto nos lleva a concluir que si el elemento encargado en la extirpación de las ido- 
latrias concedia estos acontecimientos a la parte sometida, mal se puede esperar que la catequización delimitara (como lo siguen haciendo los historiadores) cristianos e "idólatras", diferencia que no sólo es inexacta sino absurda.

\section{LOS EVANGELIZADORES}

\section{La figura del misionero}

Aun sin la lectura de testimonio de la época tendríamos que presumir la singular importancia de la figura del sacerdote en la hueste conquistadora, tanto más si pensamos la faciliclad con que el indígena captaría el sentido religioso de su autoriclad a partir de sus vestiduras y a la primera de las manifestaciones de su ministerio, la misa por ejemplo. Pero no es necesario hacer deducciones, hay una vasta documentación que, aunque de manera indirecta, nos puede dar con cierta nitidez la versión que el aborigen obtiene de la tarea eclesiástica.

Debcmos comenzar por yécalcar la situación de crisis que atravesaba la cultura andina a raíz de la invasión europea, ya licmos visto cómo ello va a desencadenar toda una serie de conflictos que el aborigen no resuelve, atenazeado por el sentimiento de culpa; pero esta vez vamos a ir más lejos, a la llegada de los españoles ya el Tahuantinsuyo era una sociedad en proceso de cambio donde las etnias y su sistema de vida chocaban con la irrupción del poder cuzqueño que empezaba a transformarlos.s. Si pensamol enotérminos de Malinowski podríamos acudir a la relación ansiedad rito, pero no es necesario, la reitcrada mención en las crónicas del aspecto religioso no solamente prueba la lógica curiosidad de los españoles sino la manifiesta preocupación de los nativos. El sacerdote llega en circunstancias que su presencia constituye un hito obligado en el pensamiento aborigen, tenía en ambas culturas el prestigio de su condición religiosa.

Hay algo más, el indígena comprende muy pronto que el sacerdote es la puerta de ingreso a la sociedad española, apenas en 1563, a treinta años de Cajamarca, el P. Quiroga al componer sus "coloquios..." recoge los denuestos que sus camaradas recibían de los vencidos, lo interesante es que al final de todos, el personaje que encarna al indígena de lo que más se lamenta es que una vez enriquecidos los misioneros abandonan su tarea: "Todos seguís un camino en esta tierra y todos lleváis un intento en vuestros intereses, porque en hartándose 
la codicia de los que nos dáis por ministros (lo qual acacsce pocas aveces en los que la tienen), luego se van y nos dexan", y es que sólo ellos o quien hiciera sus veces podía incorporarlos al nuevo mundo que se formaba dándoles el status necesario a través del bautismo y matrimonio. Resulta sintomático que al negarse a pagar tributos los indios de Végueta (encomienda de Nicolás de Rivera el Viejo) se apoyen en que durante quince años no se les ha proveido de pastor.

Lo dicho ya nos abre el camino hacia una comprensión de la cordialidad con que siempre fue recibido, muy rara vez aparecen brotes de agresión contra él, salvo una que otra reacción esporádica ante la rudeza de las "extirpaciones" o determinadas circunstancias, como la muerte de Titu Cusi, el misionero se acogió con buena fortuna al prestigio de su investitura, sin que por ello faltare la peculiar resistencia al nuevo credo de la que nos ocuparemos más adelante o la clara percepción de sus debilidades. Por lo demás, el clero siempre supo impresionar a sus ovejas no sólo a través de la prédica sino también con recursos sumamente efectivos como la visita y cuidados a los enfermos o la utilización de calaveras y pinturas alusivas en cada sermón.

Todo esto contribuye a que el sacerdote desarrolle un sistema de vida del que ya se ha escrito demasiado en pro y en contra: nosotros anotaremos lo indefenso que se hallaba el indigena frente a su pastor, puesto que llevarlo a la justicia si se daba el caso resultabá sumamente problemático, sobre todo si quienes deberían controlar su actividad constituyeron un verdadero apoyo: "...que los demás visitadores no van tanto a remediar las culpas y exessos de los doctrineros como a sus conveniencias e intereses y assi en contentando al visitador queda el doctrinero libre $y$ aunque se quejen los indios. Yo conocí un visitador y supe en la provincia de Conchucos, estando en una comissión que las mismas peticiones que le avían dado los indios contra un doctrinero se las avía dado al doctrinero y permitió Dios que nos acabase la visita, porque murió en ella" $\left({ }^{9}\right)$. Esta fuerte autoridad acrecentada por las disposiciones que permitían el castigo corporal desarrolló también una reacción contra él, perfectamente perceptible en los documentọs del XVI y vertida en las narraciones populares que circulan hasta nuestros días: "El fraile también simboliza para el indio el autor de la carestía y hambre en los ranchos, porque supone que en las grandes alforjas que lle-

(9) Padilla, Juan de. Memorial de Don (...) En: Vargas Ugarte, Rubén Historla del Perú.
Virreinato (siglo XVII). Virreinato (siglo XVII). Documento Anexo No 2, Bs. As. Librería Studium S.A. 1946,
p. 463 . 
va consigo, con el poder de la nigromancia que profesa recoge cuantos víveres encuentra dejando al pobre indio que muera por falta de ellos, con la barriga pegada al espinazo". Pero esto no implica una disminución de su poder, al contrario el indigena ha tomado conciencia de él y de sus manifestaciones.

\section{El clero, el laicado misional}

La cvangelización no es un fenómeno orgánico, los indígenas van recibiendo la doctrina de varios grupos de personas perfectamente diferenciables: los conquistadores, los frailes, los negros... circunstancias que se hizo sentir en el proceso de cristianización. Pero a riesgo de caer en el detallismo, creemos que incluso en el clero regular los nativos fueron capaces de distinguir matices diversos de acuerdo a la orden perteneciente o bien si era regular o no. Y es que los religiosos a más de llegar antes que los clérigos, mantuvieron, al menos en dos casos muy característicos (franciscanos y jesuitas), normas de comportamiento que causaron verdadero impacto en los fieles que llegaron a identificarlos con determinadas cualidades.

Sabemos bięh que mercedarios, agustinos, dominicos y franciscanos se adelantaron a la campaña, y parecía lógico que, en tanto pioneros, 'su acción fuera diferente, pensando adzmás en lo disímil de su organización, pero el problema es algo más conıplejo. Entendemos que sería conveniente analizar la situación de las cinco órdenes al momento de su arribo a América, mas lo que nos llama la atención es algo diferente: el indígena torma su propia imagen de algunas o cada una de ellas, nosotros sólo podemos hablar de dos o tres es así como los franciscanos, no sabemos por qué razón, son asociados a la muerte, incluso llegaron a creer que "... los religiosos eran difuntos, que sus hábitos eran mortajas y que, por la noche desaparecian de la tierra para ir reunirse con sus mujeres en el infierno y sólo dejaban acá su osamenta y sus hábitos...", la asociación se mantiene, el "patrón San Francisco" es la figura que guarda las puertas del más allá en el folklore andino, "los muertos van a la cima del Qoropuna... Allí se dedican a construir una torre que jamás concluyen (...). La montaña está protegida y resguardada por San Francisco"; más todavía, hay una hermosa leyenda que parece repetir la temática del viaje de Orfeo, en la que el santo cumple su papel de "guar- 
dián del país de los muertos" $\left({ }^{10}\right)$. Además la estrecha vinculación que guardó esta orden con los niños aborígenes a los que usó como instrumento de conversión fue probablemente la fuente que inspiró a los "jefes de idolatrías" a acusarlos de quebrar las cabezas de aquéllos al momento del bautismo, sacramento en el que los frailes fueron sumamente liberales.

Es posible que al hurgar en fuentes más adecuadas surjan interpretaciones de otras órdenes, como los mercedarios, cuyo celo en la organización formal de su doctrina debe haber tenido alguna repercusión en el indígena sobre todo si pensamos que parece haber sido la que más rápidamente aceptó el clero criollo y mestizo; quizá también los agustinos al usar "los propios indios como ministros de las ceremonias" nos ofrezcan un material interesante ya que la participación del aborigen siempre tuvo que estar condicionada por las circunstancias especiales que atravesaba su sociedad, además siendo ellos los primeros en admitirlos a la comunión han debido consignar la reacción ante el sacramento. El caso de los dominicos requiere manejo diferente, ellos traían una cicrta experiencia de México, allí los indígenas los calificaron de "... grandes pecadores para tener que vivir en tan apretada mortiticación"; en el Perú se establecieron en tierras de misión sumamente difícil por la fijeza de las tradiciones autóctonas: "...fueron llamados por Francisco de Talavera, Martín Pi. zarro y Gabriel de Rojas y se establecieron en las tierras de

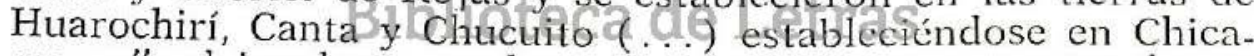
ma ...", al igual que en los casosis anteriores „estamos a la espera de poder revisar su documentación confiados que, al menos en las zonas mencionadas, aparccerán datos de importancia.

Los jesuitas constituyen todo un gran capítulo en la historia de América, aún en el estrecho margen de la evangelización aportaron técnicas nuevas provocando situaciones diferentes en razón de lo desplegado por otras órdenes. Hábiles en el aprovechamiento de situaciones difíciles, como cuando se lanzaron a predicar en las calles luego del terremoto de 1582 en Arequipa o bien utilizando las rutinarias labores de cosecha para coordinar con cantos religiosos las tareas "...prácticas que, salvo en su opuestos fines, poco se diferenciaba de aquellas otras que caracterizaban las fiestas, que, en semejantes circunstancias, los Incas hacían en honor del sol", organizan-

(10) Arguedas, José María, Puqulo, una cultura en proceso de cambio. En: Estudios sobre la cultura actual del Perú. Lima, Universidad Nacional Mayor de San Marcos, 1964. 
do, pues, de mejor forma lo que ya era tradicional en los religiosos: la presentación de su doctrina a partir de todo su aparato faustuoso que impresiona al neófito. Pero no fue suficiente, la Compañía llegó a emplear métodos tan originales como riesgosos, indios mudos y ciegos se "...transformaron en apústoles ..."; el caso de İos invidentes tomó caracteres sui géneris, por razones que desconocemos obtuvieron una rápida aceptación de su pueblo lo que entusiasmó sobre manera a sus protectores que "...los visten y dan trigo y plata y hacen mucho tratamiento porque asisten alli y enseñan y cantan la doctrina cada día", las consecuencias no se hicieron esperar; los nuevos instrumentos de la fe se convirtieron en propagadores de "idolatrías" apoyados en el prestigio conferido por los jesuitas. La explicación del fenómeno la planteamos más adelante, por ahora nos basta señalar dos aspectos: primero, que la crisis que atravesaba la sociedad andina se hace patente en estos grupos intermedios, y, segundo, el "idólatra" debió mantener su prestigio ante dos realidades de interrelación continua. Sea como fuere la labor del jesuita se dejó sentir, en cierta ocasión el "demonio" al referirse a la compañía dirá que: " $\rightarrow$ nunca se confesase (n) con ellos porque eran unos examinadores, y enganadores, etc.", lo que nos entrega una imagen de sus esfuerzos.

Párrafo aparte merece el clero secular, su tardía llegada al Perú los condena a una situación de espera o vagabundeo frente a las posicionos vactomadas por los religiosos.

Casi no existe documento que no los vapulee demostrando su frivolidad, afán de lucro y desorganización que comparada con la labor de los regulares resulta de una diferencia apreciable. Es curioso sin embargo que las fuentes revisadas no mencionan jamás una distinción especial hecha por los perspicaces ojos de los nativos, quizá el encontrarse más bien en zonas urbanas coloniales diluyó la posible observación, al menos en el período estudiado.

\section{Laicos}

Ingresamos a un terreno de singular interés, en adelante no se trata ya de la catequización organizada del clero sino más bien de remedios urgentes a falta de evangelizadores calificados, es así como surge el seglar ejerciendo estas funciones, en realidad tiene un inmediato antecedente en la propia empresa conquistadora, en ella el soldado alternó en diversas circunstancias la espada con lo poco que sabía de doctrina, 
recordemos la destruccion del santuario de Pachacamac por Hernando Pizarro y tendremos una idea clara sobre este punto. Incluso pudiera suponerse una continuidad en esta figura, en la práctica los encom nderos enseñan a su indios, pero no es ésto lo que nos llama la atención, cxistió un cierto "profesionalismo" en la difusión del cristianismo por los laicos, como dice Guamán Poma: "...antes de que hubiese padre tenía un español pobre de doctrinalle en cada provincia de este reino ya este doctrinante lo llamaba viczarayco...", se trata pues de un precario reemplazo que los españoles e indios aceptaron "... incluso tratándose de presidarios...". Es claro que la seriedad de su enseñanza se puso en tela de juicio desde el principio: ". . qué doctrina podrían dar hombres seglares o mundanos idiotas, y que apenas comunmente y por la mayor parte, se saben santiguar, a inficles de diversisima lengua a la castellana...", pero dada la situación es útil observar los efectos, en primer lugar no se trataba de un oficio como cualquier otro, quien lo aceptaba iba a gozar de una serie de prerrogativas que lo hacian importante frente a la masa indígena, además las personas que tomaron este cargo tenían casi siempre cierta predisposición a los menesteres religiosos que en algunos casos podía lindar con la insanía. La existencia de estos personajes brindó la oportunidad a más de un aventurero para que aprovechando de las circunstancias pudiera sacar partido de la veneración que tal cargo inspiraba ("I).

\section{Indios Boles ade fdiolderiasetras
"Jorge Puccinelli Converso"}

Ingresamos a un apartado vital en nuestra investigación, se trata de estudiar un grupo especial de indígenas que se aglutinó en torno al cura encontrando en él no sólo una fuen. te de prestigio sino, además, un medio de ascención social. Así como el curaca a raíz de la conquista adquirió de pronto una importancia inusitada al convertirse en el puente obligado entre invasores y vencidos, de la misma manera y en razón de los problemas de idioma primero, de la ausencia de catequizadores, y de los mismos grupos de niños auxiliares se va formando al amparo de la iglesia un núcleo de gente que sin el prestigio ancestral de los curacas adquiere poder frente a sus paișanos.

El clero no pudo prescindir de ellos, desde el descubrimiento el empleo de indígenas como intérpretes les abrió las puertas a éstos para colocarse en mayor número y con dis-

(11) Vásquez de Espinoza, Antonio. Compendio y descripción de las Indias Occidentales. Washington. The Smithsonian Institution, 1948. p. 600. 
tintas especialidades alrededor del misionero. Cuando crece la organización eclesiástica al lado de traductores o evangelizadores eventuales van a surgir sacristanes, músicos, alguaciles o fiscales, etc., es decir, todo un conjunto de personas cuya relación cor, la iglesia cristiana les había dado un status nuevo. Pero la ilegitimidad de su poder en una sociedad tradicional como la indígena y la incómoda posición de intermediario frente a cosas que comprendía muy débilmente, dotó a todo este grupo, inmerso en un mundo de transición, de caracteres conflictivos propios, sobre todo en lo que respecta a la salvaguarda de su prestigio.

Las mismas funciones que (nos referimos especialmente a los alguaciles) les tocó cumplir ya daban a su existencia un cariz poco usual, debían s'ipervisar la asistencia y cumplimiento de los nuevos cristianos en lo que respecta a su doctrina, podian visitar cada domicilio y denunciar a los remisos, tenían que controlar las enfermedades y vigilar hasta su muerte a los indígenas cuidándolos de un postrer desvio de la fe recibida, amén de fiscalizar los matrimonios y nacimientos coordinando las labores de control eclesiástico con la preocupación de descubrir cualquier "ceremonia pagana". En otras palabras desde su llegada al mundo hasta "la puesta de la mortaja" toda persona estaba conectada a la iglesia por un personaje especial participante de la misma tradición autóctona pero colocado en funciones y con atributos sin correspondencia en sus patrones culturales. Es probable, así lo creemos nosotros, que esta sea la causa esencial de su, comportamiento: el alguacil que controlaba los brotes de las nuevas formas religiosas era a la vez el jefe de ellas, igual se puede decir del sacristán que incluso hoy día acompaña al "paco" en el desempeño de sus funciones. Ante el proceso general del nacimiento de dichas formas religiosas en las que él estaba definitivamente comprometido, no podía hacer otra cosa que participar en ellas, no por esto vamos a decir que en toda "idolatría" estaba mezclado un fiscal o un mayordomo, pero de hecho tenía acceso a su formación, solicitado por sus congéneres que veían en él la persona más indicada, atendiendo al prestigio de su cargo. Tampoco podemos suponer que todos los "hechiceros" hayan estado vinculados de alguna manera con la iglesia, con toda seguridad no era indispensable para desempeñar dichas funciones pero no tenemos ordenación dentro de la vasta gama de correspondientes a lo que los españoles llamaron "hechicero", y sí en cambio, la certeza de la reiterada participación del ayudante del clero y de que toda "idolatría" arrastraba elementos católicos. 
Es por esto que la aparicion de los movimientos nativistas portadores de la idca de transformar la sociedad amparándose en elementos prehispánicos o que ellos suponían como tales, las "idolatrias" serain tan descartadas como el cristianismo (aunque de cliferente manera) en razón de que la contextura de nueva religión que iban tomando atentaba contra el desarrollo de un fenomeno que, a decir de sus lideres, "haría regresar la sociedad a tiempos del inca", dicho de otra forma la "idolatría" estaba en contra del carácter regresivo (consciente o no) de los movimientos nativistas.

Hemos analizado someramente la evangelización española, por ahora nos basta haber recorrido la mitad del camino: se ha puesto énfasis en el sentido profundo de sus efectos, queda pues su otra cara, la respuesta del catequizado. Creemos que la complejidad c!el problema necesita un largo y detenido estudio, la palabra "idolatria" ha encerrado multitud de fenómenos diferentes a los que sólo se les puede hallar un denominador común, el de constituir la (o las) respuestas del aborigen a la catequización. Pcro la investigación de este tópico requiere de armas que al momento no están a nuestro alcance: el conocimiento de las religiones prehispánicas, los problemas de cambio cultural en la naciente colonia española, etc., esto mismo podría dar lugar a una recomposición del esquema total incluso de lo eserito líneas arriba, lo que no nos aflige en absoluto ya que el mayor mérito de un trabajo no es sino el desusditar ofraschejords.

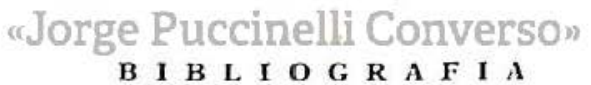

1. Almonte, Clemente. Respuesta al interrogatorio enviado al cura de Andahua (partido de Condesuyos) sobre las costumbres y organlzación de los pobladores de su jurisdicción. Santiago de Chile. Manuscrito en el Centro de Investigaciones de Historia Americana, 1965.

2. Anónimo. Apu-Inca Atawallpama. Lima, Juan Mejia Baca Editor, sin fecha. 3. Anónimo. La conquista de los españoles. Tucumán, Facultad de Filosofía y Letras,

4. Anónimo. Idolatría de los indios Huachos y Yauyos. En: Revista Histórica, Tomo VIII entrega II. Lima, Instituto Histórico del Perú, 1919.

5. Arquedas. José María. Conclusiones de un estudio comparativo entre las comunidades del Perú y España. En: Visión del Perú, No 1. Lima, Talleres Gráficos "Cecil", S.A., 1964

6. Arguedas, José Maria. Puquio, uma cultura en proceso de cambio. En: Estudios sob-e la cultura actual del Perú. Lima, Universidad Nacional Mayor de San Marcos, 1964

7. Arquedas, José María. Folklore del Valle del Mantaro. En: Folklore Americano, No 1. Lima, Comité Interamericano de Folklore, 1953.

8. Arguedas, José María. La posesión de la tierra, los mitos de origen y la visión del universo en la población monolingue quechua. Inédito. 
9. Armas Medina, Fernando de. Cristianlzación del Perú (1532-1600). Sevilla, Escuela de Estudios Hispánicos, 1953.

10. Avila, Francisco de. Parecer y arbitrio del Dr. Beneficiado de Huánuco y visitador de la Idolatría para el remedio della en Ios Indios deste Arzobispado. En: Dos documentos inéditos peruanos. Revista Histćrica. T. XI, entrega III. Lima, Instituto Histórico del Perú, 1937.

11. Boria, Francisco de Extirpación de idolatrias. En: Diez documentos del siglo XVI. Revista del Archivo Histórico, Año, IV, No 4 Cuzco, Editorial H. G. Rosas, S.A., 1953.

12. Diez de San Miguel, Garci. Visita hecha a la provincia de Chucuito por (...) en el año 1567. Lima, Casa de la Cultura, 1964.

13. Gandia, Enrique de. Historia eritica de los mitos y leyendas de la conçuista americana. Buenos Aires, Centro Difusor del Libro, 1922.

14. Garcilaso de la Vega, Inca. Historia General del Perú. Lima, Universidad Nacional Mayor de San Marcos, 1962.

15. Guamain Poma de Ayala, Felipe. Nueva Crónica y Buen Gobierno. Paris, Institute d' Ethnologie, 1935.

16. Lanternari. Vittorio, The Religions of the Oppressed. New York, The New American Library, 1965.

17. Lara, Jesuis. Tragedia del fin de Atayallpa. Cochabamba, Imprenta Universitaria, 1967.

18. Lisson Chávez, Emilio. La Iglesia de España en el Perú. Sección primera: Archivo General de Indias. Sevilla, sin pie de imprenta, 1943.

19. Mellafe, Rolando. Problemas demográficós e história colonial hispanaomericana. En: Temas de Historia Económica Hispanoamericana. Paris, Centro de Investigaciones de Historia Americana, Escala Pratique des Hautes Etudes a Institute de Haute Etudes de l'Amérique Latine, 1965.

20. Muñoz de Camargo, Dicgo. Historia de Tlaxcala. México, Ateneo Nacional, 1948.

21. Murra, John. Rebaños y pastores en la economía del Tahuantinsuyo. En: Revista Peruana de Cultura, No 2, Lima, Casa de la Cultura, 1964.

22. Otero, Gustavo Adolfo. La piedra mágica, ylda y costumbre de los indios callahuayas de Bolivla. Mexico. Instituto indigenista Interamericano, 1951.

23. Paredes, M. Rigoberto.rgitos: isupérsticiones y /supervivencias populares de Bollvia. La Paz. Imp. Atenea". De Crespi Hnos.. 1936.

24. Peña Montenegro. Alonso de la. Itinerario para varrochos de indios. Amberes, Hermanos de Tournes. 1754

25. Poiras, Diego de. Instrucción para los sacerdotes que se ocuparen de la conversión de los indios. En: Revista del Archivo Histórico, Año III, Nọ 3, Cuzco. Editorial H. G. Rosas, S. A., 1952.

26. Quiroga, Pedro de. Coloquios de In verdad. Sevilla, Centro Oficial de Estudios Americanistas, 1922.

27. Recio, Bernardo. Compendiosa relación de la cristianidad de Quito. Madrid, C.S.I.C. Instituto Santo Toribio de Mógrovejo. 1947.

28. Ricard, Roberto. La conquista esplritual de México. México, Editorial Jus Polis, 1947.

29. Romero, Carlos A. Una supervivencla del inkanato durante la Colonia. En: Revista histórica, T. X., entrega I, Lima, Instituto Histórico del Perú, 1936.

30. Rowe, John Howland. The incas under spanish colonial institutions. En: The Hispanic American Historical Review, Vol, XXXVII No 2, North Caroline, Duke University Press, 1957.

31. Rowe, John Howland. The origins of creator worship_among the incas. En: Culture in History. Essays in Honor of Paul Radin. New York, Columbia University Press, 1960.

32. Santa Cruz Pachacuti, Juan de. Relación de antiguedades desde el reyno del Piru. En: Tres relacioncs Peruanas. Asunción, Editorial Guazania, 1950. 
33. Serna, Jacinto de la. Manual de ministros para el conocimiento de sus idolatrias y extirpación de ellas. En: Relacion de decumentos ineditos para la historia de España. Tomo CIV. Madrid, Imprenta de Jose Perales v Martinez, 1892.

34. Serna, Jacinto de la; Ponce, Pedro; Feria, Peiro de. Tratado de las idolatrias, supers-

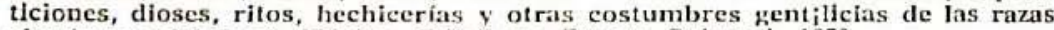
aborigenes del Perú. Mexico, Ediciones Fuente Cultural, 1953.

35. Tormo, Leandro. Historia de la Iglesia en América Latina. Madrid, Oficina Interna. cional de Investigaciones Sisciales. 1962.

36. Vargas Ugarte, Ruben. Historia de la iglesia en el Perti. (1570-16;6). Burgos, 1959.

37. Vargas Ugarte, Ruben. Concillos Limenses, (1551.1772), Lima. Talleres Grificus de la Tipografia Peruana S A. Rávagu e llijos, 1951, T. I.

38. Vásquez de Espinoza, Antonio. Compendio y descripción de las Indias Occidentales. Washington. The Smithsonian Institution, 1948.

39. Ybot León. Antonio. La iglesia y los eclesiásticos españoles en la empresa de lndlos. Barcelona, Salvat Editores S.A., $195 \%$

40. Zuidema, Reiner Tom. La organización social y política según la fuentes españolas. Madrid, Tesis doctoral, Universidad de Madrid, 1953.

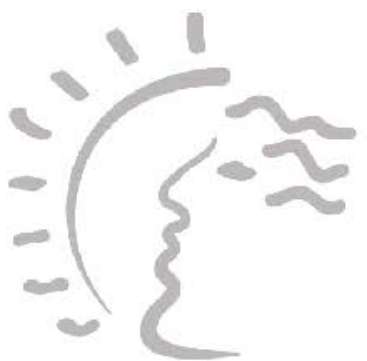

Biblioteca de Letras

«Jorge Puccinelli Converso" 